\title{
PENGARUH AIR PERASAN BROKOLI \\ TERHADAP DAYA ANALGETIK PARASETAMOL PADA MENCIT JANTAN BALB/c
}

\author{
${ }^{1}$ Maya Arfania \\ ${ }^{2}$ Lukman Hakim \\ ${ }^{3}$ Arief Rahman Hakim
}

${ }^{1}$ Prodi Farmasi Fakultas Tekhnik dan Ilmu Komputer Universitas Buana Perjuangan Karawang (maya.arfania@ubpkarawang.ac.id)

${ }^{2}$ Fakultas Farmasi Universitas Gadjah Mada Yogyakarta (lukman48@ yahoo.com) ${ }^{3}$ Fakultas Farmasi Universitas Gadjah Mada Yogyakart (ar_hakim2000@yahoo.com) Jl. HS.Ronggo Waluyo, Telukjambe Timur, Karawang, Jawa Barat 41361

\begin{abstract}
ABSTRAK
Brokoli mengandung senyawa indol yang dapat menginduksi enzim pemetabolisme obat-obat dengan rasio hepatik rendah $(<0,4)$ seperti kinidin, tolbutamide, dan parasetamol. Konsumsi bersama dengan brokoli diduga dapat menurunkan efek farmakologi obat-obat tersebut. Tujuan penelitian ini adalah untuk mengetahui pengaruh air perasan brokoli terhadap daya analgetik parasetamol.

Penelitian dilakukan menggunakan rancangan acak lengkap pola searah menggunakan hewan uji mencit jantan BALB/C. Sekelompok mencit dibagi secara acak menjadi kelompok kontrol dan perlakuan. Efek yang diamati adalah jumlah geliat dalam 1 jam. Analisa hasil dilakukan dengan membandingkan jumlah geliat rata-rata setelah perlakuan dengan parasetamol, baik dengan dan tanpa pemberian air perasan brokoli. Jumlah geliat rata-rata yang timbul akibat pemberian asam asetat dan parasetamol, baik dengan dan tanpa pemberian air perasan brokoli dibandingkan secara statistik menggunakan uji Student's-t tak berpasangan dengan taraf kepercayaan $95 \%$.

Hasil penelitian menunjukkan air perasan brokoli dapat meningkatkan daya analgetik parasetamol pada mencit (dari $54,74 \%$ menjadi $71,58 \%$ ) dengan perbedaan tidak bermakna $(p>0,05)$.
\end{abstract}

Kata kunci: Brokoli, parasetamol, analgetik 


\begin{abstract}
Broccoli contains indole compounds that can induce metabolic enzymes of drugs with low hepatic extraction ratio $(<0,4)$ such as quinidine, tolbutamide, and paracetamol. Consumption with broccoli was suspected to decrease the pharmacological effect of these drugs. The objective of the present study is to determine the effect of broccoli juice to the analgesic of paracetamol.

The study was conducted in male BALB/C mice using a randomized completely block design. A group of mice were randomly divided into control and treatment groups. The observed effect is the cummulative number of stretching in an 1 hour. The results were analyzed by comparing the average number of stretching after treatment with paracetamol, both with and without the broccoli juice pretreatment. The average number of stretching with and without broccoli juice administration were compared statistically using an independent Student's t Test with 95\% confidence level.

The results show that broccoli juice can increase the analgesic effect of paracetamol in the mice (from $54,74 \%$ to $71,58 \%$ ) without significantly difference (p > $0,05)$.
\end{abstract}

Keywords: Broccoli, paracetamol, analgesic

\title{
PENDAHULUAN
}

Sayur-sayuran dari familia Brassicaceae yang lazim dikonsumsi ternyata dapat mempengaruhi profil farmakokinetika obat dan pada gilirannya mempengaruhi farmakodinamika obat. Hasil penelitian yang telah dilakukan sebelumnya menunjukkan bahwa praperlakuan brokoli pada kelinci menyebabkan perubahan parameter farmakokinetik kinidin, antara lain penurunan kadar puncak dan luas area di bawah kurva kinidin, terjadi kenaikan pada volume distribusi dan kliren hepatik kinidin secara bermakna. Perubahan farmakokinetik kinidin secara bermakna akibat praperlakuan brokoli juga dijumpai pada pemberian kinidin per oral (Sari, 1999). Dari penelitian tersebut disimpulkan bahwa brokoli mampu mempengaruhi sistem enzim biotransformasi kinidin yaitu sitokrom P-450 3A4. Penelitian lain mengenai pengaruh perasan brokoli terhadap farmakokinetik tolbutamid pada tikus normal menunjukkan 
bahwa terjadi kenaikan kliren hepatik dan volume distribusi tolbutamid secara bermakna. Perubahan kedua parameter tersebut menurunkan jumlah tolbutamid dalam sirkulasi sistemik (Nugroho, 2000). Gejala ini mengindikasikan bahwa brokoli mampu menginduksi sistem enzim biotransformasi tolbutamid, yaitu enzim sitokrom P-450 2C8, 2C9 dan 2C19.

Menurut Rowland dan Tozer (1995), kinidin, tolbutamid, salisilat, parasetamol, dan fenobarbital adalah obat-obat yang memiliki rasio ekstraksi hepatik rendah, yaitu kurang dari 0,4. Pada obat-obat ini, nilai kliren hepatik (CLh) dan kliren total (CL) dapat dipengaruhi oleh induksi enzim metabolismenya. Di lain pihak Bradfield dan Bjeldanes (1991) menyatakan bahwa senyawa indol yang terkandung pada Brassica sp dapat mempengaruhi kerja enzim-enzim sitokrom P-450 tergantung monoksigenase, glutation S-transferase atau epoksi hidrolase. Pustaka lain menyebutkan bahwa kubis dan brokoli mengandung senyawa indol yang mampu menginduksi dealkilasi- Ofenasetin, dealkilasi-O-7-etoksikumarin, hidroksilasi dari benzo[a]piren dan heksobarbital dealkilasi-O dari fenasetin dan 7-etoksikumarin pada tikus serta dapat memperlihatkan induksi biotransformasi antipirin dan fenasetin, glukuronidasi parasetamol dan aktivitas glutation transferase pada manusia (Pantuck dkk,1976; Beecher, 1994; Cashman dkk, 1999; Gibson dan Skett, 1986).

Parasetamol merupakan senyawa turunan para-aminofenol yang berfungsi sebagai analgetik-antipiretik. Obat ini adalah penghambat pembentukan prostaglandin yang lemah pada jaringan perifer dan tidak memiliki efek antiinflamasi yang bermakna. Daya kerjanya sebagai analgetik sama kuatnya dengan aspirin namun lama kerjanya sedikit lebih singkat (Tjay dan Rahardja, 2002). Parasetamol dimetabolisme utamanya di hati, sebagian besar diubah menjadi bentuk tidak aktif oleh konjugasi dengan sulfat dan glukuronida, yang kemudian diekskresi melalui ginjal. Hanya sebagian kecil parasetamol yang dimetabolisme melalui sistem enzim sitokrom P450 hepatik terutama CYP 2E1 (Zimmerman dan Maddrey, 1995). Parasetamol merupakan obat dengan rasio ekstraksi hepatik rendah (Rowland dan Tozer, 1995), sehingga obat ini mudah mengalami induksi enzim. Konsumsi brokoli bersama dengan obat dengan rasio ekstraksi hepatik rendah (misalnya parasetamol), diduga dapat mengurangi efek farmakologi parasetamol sehingga dapat menyebabkan tidak tercapainya efek terapi yang diinginkan. 
Dengan mengacu pada penelitian-penelitian sebelumnya yang telah membuktikan adanya interaksi antara sayuran dari familia Brassicaceae dengan obatobatan rasio ekstraksi hepatik rendah, maka perlu dilakukan penelitian untuk mengetahui apakah brokoli dapat mempengaruhi efek farmakologi parasetamol,. Tujuan penelitian ini adalah untuk mengetahui pengaruh air perasan brokoli terhadap daya analgetik parasetamol pada mencit jantan BALB/c.

\title{
METODE PENELITIAN
}

\section{Bahan}

Parasetamol berkualitas farmasetis, asam asetat glasial pro analisa, brokoli, akuabides, mencit jantan galur BALB/c berat 20-30 gram umur 2-3 bulan. Air perasan brokoli diperoleh dengan memeras brokoli menggunakan blender, tanpa pengenceran air.

\begin{abstract}
Alat
Timbangan mencit, jarum per oral $(5 \mathrm{ml})$, jarum suntik intraperitoneal $(1 \mathrm{ml})$, pipet tetes dan pipet Ependorf, labu takar 10, 50, $100 \mathrm{ml}$, labu Erlenmeyer, dan beaker glass, mortar, dan stamper.
\end{abstract}

\section{Perlakuan hewan uji}

Tanpa pra-perlakuan air perasan brokoli

Kelompok asam asetat:

Lima ekor mencit disuntik larutan asam asetat (100 mg/kg; ip), kemudian dihitung jumlah geliat yang muncul.

Kelompok parasetamol:

Enam ekor mencit disuntik larutan asam asetat (100 mg.kg; ip), dan 15 menit kemudian diberi larutan parasetamol (91 mg/kg; po), dan dihitung jumlah geliat yang terjadi.

Dengan pra-perlakuan air perasan brokoli

Kelompok parasetamol:

Lima ekor mencit diberi air perasan brokoli (50 ml/kg; po) dengan 7-kali pemberian (3kali sehari). Lima jam setelah pemberian brokoli yang terakhir, mencit disuntik larutan asam asetat (100 mg/kg; ip), dan 15 menit kemudian diberi larutan parasetamol (91 $\mathrm{mg} / \mathrm{kg}$; po). Dihitung jumlah geliat yang terjadi. 


\section{Analisa dan uji statisitik}

Daya analgetik ditentukan dengan persamaan berikut:

$$
\text { Daya Analgetik }=\frac{\sum \text { geliat rata-rata (asam asetat }- \text { parasetamol) }}{\sum \text { geliat rata-rata asam asetat }} \times 100 \%
$$

Uji statistik:

Jumlah geliat rata-rata yang timbul akibat pemberian asam asetat dan parasetamol, baik dengan dan tanpa pemberian air perasan brokoli dibandingkan secara statistik menggunakan uji Student's-t tak berpasangan dengan taraf kepercayaam 95\%.

\section{PEMBAHASAN}

Uji analgetik dalam penelitian ini menggunakan metode rangsang kimia berupa tumbulnya rasa nyeri karena pemberian asam asetat secara intraperitoneal. Manifestasi timbulnya rasa nyeri yaitu berupa geliat. Karakteristik geliat yang digunakan sebagai patokan adalah geliat dengan bentuk minimum 1-2 geliat, yaitu kedua pasang kaki depan ditarik ke depan dan kedua kaki belakang ditarik ke belakang sehingga perut menekan alas kandang dalam waktu 5 menit setelah pemberian asam asetat (Vogel, 2002).

Dosis asam asetat yang digunakan adalah $100 \mathrm{mg} / \mathrm{kg}$. Pengamatan geliat dilakukan selama 1 jam dan didapatkan geliat rata-rata $(M \pm S E M)$ sebesar $95 \pm 10$, dengan kisaran geliat sebesar 70-124, seperti disajikan pada tabel.

Tabel . Persentase daya analgetik parasetamol dengan dan tanpa pra perlakuan brokoli pada mencit jantan BALB/c

\begin{tabular}{ccc}
\hline Perlakuan & $\begin{array}{c}\text { Jumlah geliat kumultaif } \\
(\mathrm{M} \pm \mathrm{SEM})\end{array}$ & \% Daya Analgetik \\
\hline Asam asetat & $95 \pm 10$ & 0 \\
Parasetamol & $43 \pm 11$ & 54,74 \\
Parasetamol + brokoli & $27 \pm 7$ & 71,58 \\
\hline
\end{tabular}

Untuk menguji daya analgetik parasetamol, mencit jantan BALB/c yang telah diberi asam asetat (100 mg/kg; ip) dan 15 menit kemudian diberi parasetamol dosis 91 $\mathrm{mg} / \mathrm{kg}$ per oral. Ternyata jumlah geliat setelah pemberian parasetamol berkurang secara bermakna bila dibandingkan dengan pemberian asam asetat saja $(95 \pm 10)$ dan 
didapatkan rata-rata geliat $43 \pm 11$, atau berkisar antara 3-63 dengan $\%$ daya analgetik sebesar 54, 74\% ( $p<0,05)$. Hal ini dapat dilihat pada gambar 1 .

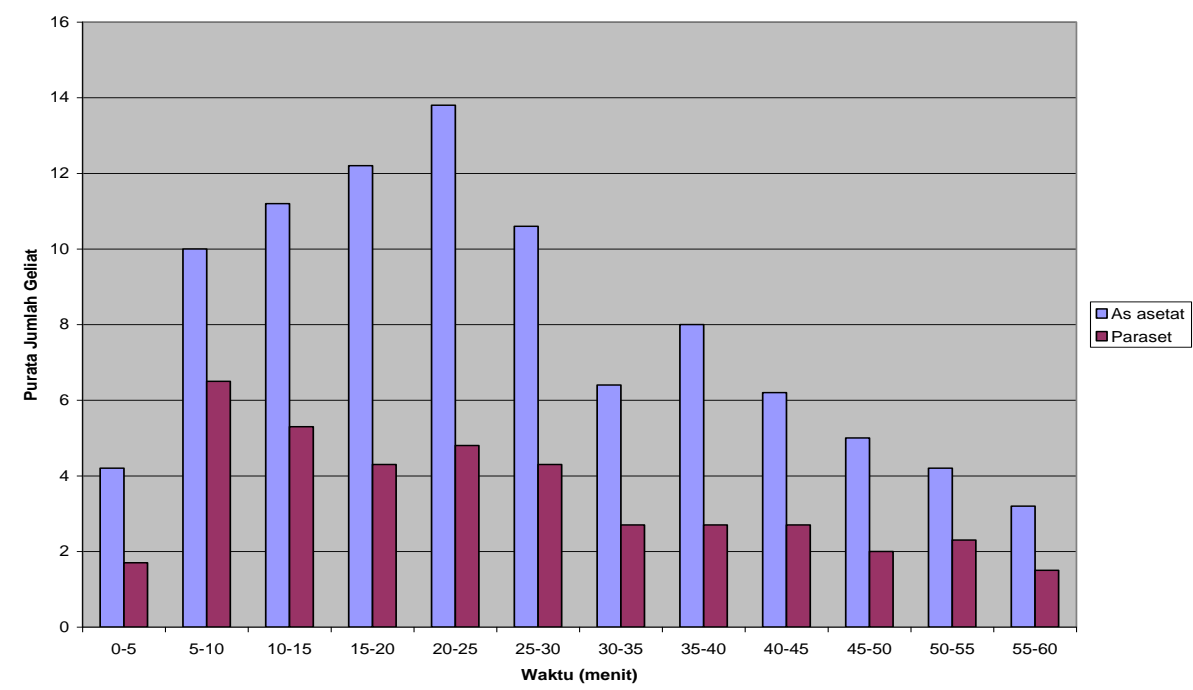

Gambar 1. Jumlah geliat rata-rata pada tiap-tiap interval waktu pengukuran setelah pemberian asam asetat $(100 \mathrm{mg} / \mathrm{kg}$; ip) dan larutan parasetamol $(91 \mathrm{mg} / \mathrm{kg}$ per oral $)$ pada mencit jantan BALB/c

Untuk menguji daya analgetik parasetamol setelah pemberian brokoli, dilakukan setelah mencit jantan diberi air perasan brokoli $(50 \mathrm{mg} / \mathrm{kg}$ per oral). Pemberian air perasan brokoli dilakukan selama 3 hari berturut-turut dengan waktu pemberian 3 kali sehari selama 2 hari dan 1 kali pada hari ketiga. Lima jam setelah pemberian terakhir brokoli, mencit disuntik asam asetat (100 mg/kg; ip) dan 15 menit kemudian diberikan parasetamol (91 mg/kg; po). Setelah pemberian parasetamol diamati jumlah geliat yang muncul selama 1 jam dan didapatkan jumlah geliat rata-rata $(\mathrm{M} \pm \mathrm{SEM})$ adalah $22 \pm 7$ geliat (berkisar 12-43 geliat). Dengan kata lain, pemberian air perasan brokoli mampu meningkatkan daya analgetik parasetamol sebesar 71,58\% (tabel).

Jika dibandingkan antara perlakuan dengan dan tanpa air perasan brokoli, ternyata jumlah geliat parasetamol berkurang, dari $43 \pm 11,3$ (tanpa brokoli) menjadi 27 \pm 7 (dengan brokoli), seperti nampak pada gambar 2. Dari temuan ini ternyata terjadi peningkatan \% daya analgetik parasetamol dari 54,74\% (tanpa brokoli) menjadi 71,58\% (dengan brokoli), meskipun perbedaan tersebut tidak bermakna $(p>0,05)$. 


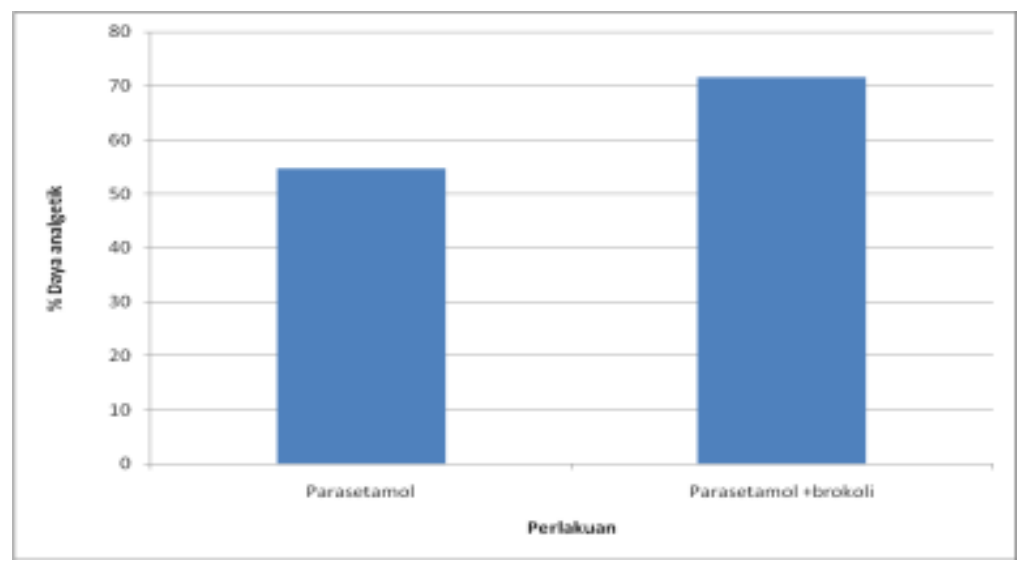

Gambar 2. Persen daya analgetik parasetamol (91 mg/kg BB; per oral) dengan dan tanpa pra perlakuan air perasan brokoli ( $50 \mathrm{ml} / \mathrm{kg} \mathrm{BB}$; per oral; 7x pemberian) pada mencit jantan BALB/C

Dalam penelitian ini, daya analgetik parasetamol tidak terpengaruh oleh adanya senyawa kimia dalam brokoli. Hal ini mungkin disebabkan karena parasetamol sebagian kecil (5-10\%) mengalami biotransformasi melalui isozim P450 2E1, dan sebagian besar melalui fase II (konjugasi; 60 - 90 \%; Zimmerman dan Maddrey, 1995). Sedangkan brokoli lebih berperan mempengaruhi enzim sitokrom P450 3A. Alasan ini diperkuat oleh Ritschel (1992), bahwa biotransformasi parasetamol melalui fase II, yaitu konjugasi dengan sulfat dan asam glukuronat. Jadi dari hasil penelitian ini dapat disimpulkan bahwa zat aktif brokoli tidak mampu menginduksi enzim metabolisme parasetamol baik pada fase I maupun fase II pada mencit jantan BALB/c.

\section{PENUTUP}

\section{Kesimpulan}

Hasil penelitian menunjukkan air perasan brokoli dapat meningkatkan daya analgetik parasetamol pada mencit (dari 54,74\% menjadi 71,58\%) dengan perbedaan yang tidak bermakna $(p>0,05)$.

\section{Saran}

1. Perlu dilakukan penelitian lebih lanjut tentang kemungkinan interaksi senyawasenyawa yang terdapat di dalam brokoli pada proses distribusi atau ikatannya dengan reseptor yang bertanggung jawab terhadap efek parasetamol.

2. Perlu dilakukan penelitian lebih lanjut pada obat lain, khususnya yang memiliki rasio ekstraksi hepatik rendah, misalnya teofilin, digoksin, kloramfenikol, klordiazepoksid, sehingga didapatkan informasi yang lebih lengkap mengenai adanya pengaruh 
konsumsi sayur-sayuran dari Brassicaceae terhadap obat-obatan yang lazim digunakan dalam terapi.

3. Dosis dan lama pemberian air perasan brokoli perlu ditingkatkan untuk membuktikan adanya pengaruh pada metabolisme (khususnya fase II) dari parasetamol.

\section{DAFTAR PUSTAKA}

Beecher, C.W.W. 1994, Cancer Prevention Properties of Varieties on Brassica oleraceae : A Review. Am. J. Clin. Nutr, 59 (suppl) : 1165S-1170S.

Bradfield, C.A \& Bjeldanes, L.F. 1991, Modification of carcinogen metabolism by indolylic autolysis product of Brassica oleracea, Adv. Exp. Med. Biol. 289: 153-163.

Cashman, J.R., Xiong, Y., Lin, J., Verhagen, H., van Poppel, G., van Bladeren , P.J., Larsen-Su, s., and Williams, D.S. 1999, In Vitro and In Vivo Inhibition of Human Flavin-Containing Monooxygenase Form 3 (FMO3) in The Present of Dietary Indoles, Biochem. Pharmacol., 58 : 1047-1055.

Gibson, G.G \& Skett, P. 1986, Introduction to Drug Metabolism, 1-42, Chapman and Hall, London.

Nugroho, A.E. 2000, Pengaruh Praperlakuan Brokoli (Brassica oleraceae L.) Terhadap Farmakokinetika Tolbutamid pada Tikus Putih Jantan, Laporan Penelitian, Lembaga Penelitian UGM, Yogyakarta.

Pantuck, E.J., Hsio, K.C., Loub, W.D., Wattenberg, L.W., Kuntzman, R. and Conney, A.H. 1976, Stimulatory Effect of Vegetales on Intestinal Drug Metabolism in The Rat, J.Pharmacol. Exp. Ther., 198 : 278-283.

Ritschel, W.A. 1992, Handbook of Basic Pharmacokinetics, $4^{\text {th }}$ ed., Drug Intelligence Publications, Inc., Hamilton.

Rowland, M \& Tozer, T.N.1995, Clinical Pharmacokinetics : Concepts and Applications, $3^{\text {rd }}$ ed., Lippincott Williams \& Wilkins, A Wolters Kluwer Co., Philadelphia.

Sari, I.P. 1999, Antaraksi Farmakokinetika Brokoli (Brassica oleraceae L. vabrotrytis L.)-Kinidin. Kajian Terhadap Akibat dan Perantara Antaraksi, Fakultas Farmasi Universitas Gadjah Mada, Yogyakarta.

Tjay, H.T dan Rahardja, K. 2002, Obat-Obat Penting, Edisi Kelima, Ditjen Pengawasan Obat dan Makanan, Departemen Kesehatan Repulik Indnesia, Jakarta. 
Vogel, H.G. 2002, Drug discovery and evaluation-Pharmacologigal assays, Springer: 716.

Zimmerman, H.J \& Maddrey, W.C, 1995, Acetaminophen (paracetamol) hepatotoxicity with regular intake of alcohol: analysis of instances of therapeutic misadventure. Hepatology 22 (3): 767-773. 